\title{
The Reading Habits of Malaysian Chinese University Students
}

\author{
Dr Mohamad Jafre Zainol Abidin \\ School of Educational Studies, University of Science Malaysia (USM) \\ 11800 Gelugor, Penang Island, Malaysia \\ E-mail: Jafre@usm.my
}

Majid Pour-Mohammadi (Corresponding author)

Department of English Translation, Islamic Azad University, Rasht, Iran

PO Box 129, Rasht, Iran

Tel: +60 $176054350 \quad$ E-mail: majid.pourmohammadi@gmail.com

\author{
Ooi Choon Lean \\ School of Educational Studies, University of Science Malaysia (USM) \\ 11800 Gelugor, Penang Island, Malaysia \\ E-mail: Lucy_ooi@yahoo.com
}

Received: October 28, 2011 Accepted: November 3, 2011 Published: December 1, 2011

doi:10.5296/jse.v1i1.1037 URL: http://dx.doi.org/10.5296/jse.v1i1.1037

\begin{abstract}
It is assumed that all students read. This study was set to examine the reading habits of Malaysian Chinese students in the current era of technology and electronics. It also investigated if early intervention in reading would influence current reading habits. A questionnaire was used to investigate the participants' general attitudes towards reading and their reading preferences. The gathered data highlighted what motivates students when they read for leisure and their preferred language of reading materials. In addition, it was revealed that the participants prefer the electronic media when reading for leisure but prefer the printed media to pass exams. The results are finally discussed.
\end{abstract}

Keywords: Reading habit, Malaysian Chinese, University student, Electronic media, Leisure 


\section{Introduction}

Reading is generally accepted as a way of reaching new information and new knowledge. Besides, it is an essential language skill for successfully completing all college-level courses. That is, college students who are more proficient readers are most likely to experience more success in their courses (Kim \& Anderson, 2011). It is not only to increase knowledge but also to build maturity and widen awareness of contemporary issues. A good reading habit is an important tool for the development of personalities and mental capacities. The reading habits of the young people in Malaysia have long been the concern of educators and policy makers. Studies in Malaysia have reported that Malaysian students read very little (Kaur \& Thivagarajah, 1999). Many of them prefer to watch television and video to reading for information or leisure. Malaysian teachers have often complained about the poor reading habits among their students. Pandian (2000) found that the majority of university students are "reluctant" readers in English language materials. Based on his study, the Chinese were behind the Indian and Malay students as habitual readers in the English language. However, it cannot be said that Chinese students do not read, as many available reading materials are in Chinese.

\subsection{Background of Malaysian Chinese Students}

The local Chinese students in Malaysia are usually bilingual or trilingual. In recent years, as many as $95 \%$ of Chinese parents choose to send their children to Chinese stream primary schools purportedly to learn their culture. In these schools, Bahasa Malaysia is a compulsory subject and English is taught as a language subject. When students go to secondary school, more than half of Chinese students choose to go to public secondary schools where the main teaching language is Bahasa Malaysia. Students can take Chinese as an elective subject in the major exams or not sit for it. Yet, many Chinese students continue to communicate in Mandarin to fellow Chinese friends even though school texts are in Bahasa Malaysia or English. When students choose to read for leisure, they often choose to read in the language they are most comfortable in- mainly Chinese materials. They only read in Bahasa Malaysia and English for the purpose of passing exams.

Chinese students are also said to be more tech savvy as they are more exposed to the electronic media because most Malaysian Chinese live in urban areas. Literature review on reading has shown that readers' background, home and peers can affect their reading habits. Chinese parents also tend to be keener at encouraging use of the electronic media as they see it as another mode of learning. Many Chinese families have computers and other electronic gadgets at home. Chinese primary schools often have computer classes as extra-curricular subjects so Chinese students are often exposed to technology early.

\subsection{Reading Habits in the Current Era of Technology}

With the advancement of the electronic media, it may be said that students now read even less as they get more involve in watching TV and playing electronic games in their spare time. The electronic media has changed the way people perceive reading and how printed materials are being utilized for reading. The growth of the electronic media as a source of information 
and entertainment has been phenomenal. More and more people, especially the young, are going wireless and using the web to gather information. Many young people have abandoned hardcopies such as books for softcopies such as movies and videos. Reading the hardcopy is seen as to take too long and too much hard work. Technology for classroom promises that students will have a more engaging platform, more like watching TV, but with the potential to provide truly individualized instruction. It seems that the digital media is here to stay. However, will Malaysian students who hardly read, find reading on electronic media more interesting?

\subsection{Research Objectives and Questions}

The main objective of this study is to determine the reading materials that Malaysian Chinese college students prefer when they read for leisure. It also seeks to determine the preferred choice in reading media, digital or print, as well as the preferred language. The secondary objective is to investigate if there is any relationship between early reading experiences and current reading habits. It is assumed that all students have to read, but their choices of reading material during leisure definitely differ from those for academic purpose. This study attempted to answer the following questions.

1. What do Malaysian Chinese college students read for leisure?

2. What media, digital or print, do they prefer when reading for leisure?

3. What language do they prefer when reading for leisure?

4. Is there any relationship between early reading experiences and their current reading habits?

\section{Literature Review}

Researchers have found a lot of changes in the reading habits of college students due to the impact of digital media made available through the internet (Liu, 2005). Recreational reading has changed for young adults and students in an era of eBooks and laptops and hours spent online. Students have been known to be very receptive to different forms of media. With the advent and evolution of the internet, information can be transmitted quickly. Reading time using digital media is made shorter by skimming and browsing the hypertexts that are less structured and non-linear. Liu (2005) found that younger people can tolerate more time reading screen-based materials. However, students tend to print out material (for school) to read more slowly. Research has found that reading traditional books has gone down but students could be reading on cell phone, in games on the web and on the computer. For students to make reading pleasurable and continue the reading habit, they need to stay abreast with the advancement of technology. If reading online and in game playing is taken into account, then the digital age has probably increased reading. Search engines are now available in Chinese for people who have a preference to read in Chinese. This would encourage more students who are tech savvy to read for leisure.

A study conducted by Nor Shahriza and Amelia (2007) focused on the gender and choice of reading material by university students revealed that university students spend a significant 
amount of time reading newspapers, academic books and websites. Not surprisingly, they reported that IT-based students tend to use electronic resources more than art based students. Kaur and Thivagarajah (1999) did a study on the English reading habits of students at University Sains Malaysia and found that students are motivated to read in English as they knew that it would improve their English proficiency so as to get good grades in their courses. The students spent little time on leisure reading but 3-5 hours a week on literary works and ELT books. Similarly, Yang (2007) found that in many EFL situations, English is learned as an examination subject rather than a tool for life. Most students do not use English outside the classroom so they read English books only as requirement and not for leisure.

A study by Shen (2006) in Taiwan indicated that the reasons for leisure reading were for entertainment and acquiring information. Magazines and newspapers were found to be the most preferred reading materials of young adults. Over $70 \%$ of undergraduate students preferred to read magazines and newspapers to novels with half of them reading the sports and entertainment news regularly.

The technology driven lifestyle is definitely changing the reading habits of the young. Studies on reading among college students have gained much attention in recent years due to the impact of the digital media. More and more students are using technology to satisfy their information needs. Books, newspapers and other printed media are now considered old-fashioned. Such traditional media have to adapt to meet the challenges of the new age. Several news websites and on-line news providers such as Malaysiakini have been started to compete with the printed media and major book publishers have made many of their latest publications digital. In July 2010, the ComScore. Inc., an internet information company, released ranking of the top News/Information sites in Malaysia. According to the release, the report found that 5.5 million Malaysians age 15 and above who went online visited a News/information site. The Star.com.my was the most visited local news channel. However, most of the studies done in Malaysia are done with a combination of all the races and the Chinese make up the minority. Therefore, the results may not show the correct picture of Chinese as readers.

Researchers and educators have widely recommended that good reading habit has to begin early and that there should be a conducive reading environment to stimulate lifelong reading (Berk, 2009; Ormrod, 2006; Pandian, 2000). Students rarely read for pleasure. Reading is part of "studying" or school work. When reading has not been formed as a habit, holding a book will be considered a part of school work (Yang, 2007). Parents are the most influential people in the lives of children. Children learn by modelling and parents who put value to reading and read themselves will promote a reading culture at home. If parents do not make reading a daily activity, they should not expect their children to read. According to Pandian (2000), the factors related to students' background, home and school have an impact on their reading behaviour. He mentioned that the cultivation of reading is influenced by a range of factors like exposure to media and computers.

Many early childhood educators believe that promoting positive reading habits in young children helps make them readers for life. By the time children start to read when they start 
formal education, they associate reading with exams and not pleasure. Even though children cannot decipher the letters when they are young, they mimic adult behaviour, believing they are "reading". Children who are brought upon a healthy diet of books, shared with caring adults, want to master the skills they need to read.

Research shows that when we read and talk to children, they learn to read naturally because they want to. Parents who encourage reading and allow their children to read books which discuss the topics of their interest will encourage reading for pleasure and personal interest which will translate into good academic performance. Chinese parents in Malaysia are famously concerned about their children's education and many send their children for extra tuition classes from a young age. Although some parents do not have good reading habits because they claim to be too busy, they would send their young children for early reading classes as they believe that ability to read would cultivate intellectual, social, spiritual and personal development. Does parents' decision of sending their children to usually foreign child enrichment programs such as Lorna Whiston, Genius Brain Centre and Mental Arithmetic classes see results and provide their children with life long reading habit?

\section{Procedure}

In this study, in order to explore the reading habits among the Chinese students, a survey research method was applied. That is, a questionnaire was randomly given to 60 Chinese students studying at University Tunku Abdul Rahman (UTAR) (see Appendix). The respondents were 26 males and 34 females. The students at UTAR are mainly Malaysian Chinese who come from all the states in Malaysia. They form a convenient sample of Chinese students from both urban and rural areas in Malaysia. UTAR offers courses at degree level and has over 12,000 students. The students marked the questionnaire and returned it immediately in return for a small reward.

\section{Findings and Discussion}

As expected, $81.7 \%$ of the respondents went to Chinese primary school and $78.3 \%$ went to national secondary school (Table 4.1). Only 4 out of the 60 respondents never learned Mandarin in school and thus do not read or write in Chinese.

Table 4.1. The Demographic Information of the Respondents

\begin{tabular}{|l|l|l|}
\hline & 60 & $\%$ \\
\hline male & 26 & 43.3 \\
\hline female & 34 & 56.7 \\
\hline Went to Chinese primary school & 49 & 81.7 \\
\hline National primary school & 11 & 18.3 \\
\hline Chinese independent school & 13 & 21.7 \\
\hline National secondary school & 47 & 78.3 \\
\hline Chinese literate & 56 & 93.3 \\
\hline Cannot read and write Chinese & 4 & 6.7 \\
\hline
\end{tabular}


More than $85 \%$ of the respondents speak either dialect or Mandarin at home with their family members and 13\% use a mixture of English and Chinese (Table 4.2). Only 1 respondent speaks English at home.

Table 4.2. Languages Spoken at Home

\begin{tabular}{|l|l|l|}
\hline & 60 & $\%$ \\
\hline dialect & 8 & 13.3 \\
\hline Mandarin & 21 & 35 \\
\hline Dialect and Mandarin & 21 & 35 \\
\hline English & 1 & 1.7 \\
\hline English and Mandarin & 8 & 13.3 \\
\hline English and dialect & 1 & 1.7 \\
\hline
\end{tabular}

With their Chinese friends, $42 \%$ of students speak dialect or Mandarin while $56 \%$ prefer a mix of English and Chinese (Table 4.3). Only 1 student uses English when speaking with Chinese friends. None of the respondents speaks Bahasa Malaysia with his/her Chinese friends. This could be because all courses in UTAR are conducted in English and the students might be polishing their conversational English by practicing with their friends.

Table 4.3. Languages Spoken with Friends

\begin{tabular}{|l|l|l|}
\hline & 60 & $\%$ \\
\hline Dialect & 2 & 3.3 \\
\hline Mandarin & 17 & 28.3 \\
\hline Dialect and Mandarin & 6 & 10 \\
\hline English & 1 & 1.7 \\
\hline English and Mandarin & 34 & 56.7 \\
\hline
\end{tabular}

Contrary to earlier research, the results of this survey showed that many students do read as almost half of the 60 respondents read in their spare time. Around $48 \%$ of respondents said they read in their spare time (Table 4.4). This survey indicated that they may be reading mostly newspapers, magazines and comics but it is still reading. Fifty five, 91\%, of the respondents said they surf the net in their spare time. What the students actually do when they surf the net is debatable but surfing the net will require a certain amount of reading. When students $\log$ on to Facebook or YouTube, they read and write as they 'chat' and share information back and forth. Around 38\% said they played computer games in their spare time and half or $50 \%$ said they watch TV. Their choice of TV programs and the language they were in was not recorded but watching TV sometimes entail reading of the subtitles especially when the program is foreign such as the popular Korean dramas. When they watch English programs, they might be reading the subtitles, too. Only $26 \%$ claimed they spend their spare time playing sports. 
Table 4.4. Activities Done in Spare Time

\begin{tabular}{|l|l|l|}
\hline & 60 & $\%$ \\
\hline Surf the net & 55 & 91 \\
\hline Play computer games & 23 & 38 \\
\hline Watch TV & 30 & 50 \\
\hline Play sports & 15 & 26 \\
\hline read & 2 & 3.3 \\
\hline
\end{tabular}

Concerning the reasons the respondents read, $66 \%$ of them said they read because they need to pass exams and $40 \%$ said they read because they think they should (Table 4.5). Moreover, $40 \%$ said they read because they are interested in a topic or subject. This shows that students really spend most of their reading time on school work and assignments but they could be nudged into reading for information through mandatory reading. Only 10\% said they read because they think reading is fun and $20 \%$ said they read to pass some time.

Table 4.5. Reasons for Reading

\begin{tabular}{|l|l|l|}
\hline & 60 & $\%$ \\
\hline I think I should & 24 & 40 \\
\hline I need to pass exams & 40 & 66 \\
\hline I am interested in the topic & 24 & 40 \\
\hline I need to while away some time & 12 & 20 \\
\hline
\end{tabular}

However, the time students spend on reading tasks is arguable. Around $75 \%$ of them spend less than two hours on reading per day, including the $42 \%$ who spend time reading text books (Table 4.6). In addition, 70\% spend their reading time on-line while surfing the net and 37\% read light reading materials such as newspaper, comics and magazines. The time spent reading would naturally increase during the period before exams. Only two of the respondents said they like to read novels or story books.

Table 4.6. Time Spend on Reading

\begin{tabular}{|l|l|l|}
\hline & 60 & $\%$ \\
\hline Less than 1 hour & 22 & 36.7 \\
\hline 1 to 2 hours & 23 & 38.3 \\
\hline 2 to 3 hours & 9 & 15 \\
\hline 3 to 4 hours & 4 & 6.7 \\
\hline More than 4 hours & 2 & 3.3 \\
\hline
\end{tabular}

Around $75 \%$ of them prefer hardcopies when reading materials such as magazines, newspapers and text books. Chinese students showed no clear preference when choosing language of reading material. About 33\% preferred Chinese material while $28 \%$ preferred English materials yet $38 \%$ of respondents read in both English and Chinese. As all courses are taught in English, all related text books are also in English and assignments have to be written in English. Very few students choose to read materials in Bahasa Malaysia. 
The respondents are all tech savvy as $91 \%$ of them surf the net in their spare time. All of them have Facebook accounts with $43 \%$ of them having more than 1 portfolio such as MSN and YouTube. As many of the respondents are bilingual, they prefer to communicate in both Chinese and English with their Chinese friends when they are on-line. More than $50 \%$ of them prefer to use search engines in English and visit English websites. This could be because reading for assignments at school would require them to do their research in English. The $15 \%$ who like to visit Chinese websites maybe doing so for leisure. Around $28 \%$ said they use both Chinese and English websites. Unlike the time spent on reading hardcopies, more than $35 \%$ of the respondents said they spend more than 4 hours every day on the computer (Table 4.7). Only 10\% spend less than 1 hour on-line. The others usually spend from 2 to 4 hours on-line every day.

Table 4.7. Time Spent Online

\begin{tabular}{|l|l|l|}
\hline Time spent on-line & 60 & $\%$ \\
\hline Less than 1 hour & 2 & 3.3 \\
\hline 1 to 2 hours & 6 & 10 \\
\hline 2 to 3 hours & 18 & 30 \\
\hline 3 to 4 hours & 13 & 21.7 \\
\hline More than 4 hours & 21 & 35.5 \\
\hline
\end{tabular}

The time spent on-line could be spent in their chat rooms more than on reading. Yet, it could still be considered reading as they have to read what their friends write. More than $80 \%$ spend 1 to 2 hours playing games on-line. When on-line, more than $60 \%$ of respondents read on-line articles and journals and $50 \%$ of them read on-line news. About $29 \%$ of respondents go on-line to look for and read information that interests them such as gaming information. When on-line, $75 \%$ of respondents prefer to read direct off the screen. Only $25 \%$ print out information to read at leisure.

The survey disclosed that $78 \%$ of the respondents learned to read before they went to primary school but only 14 out of the 60 respondents said that they went for special reading classes when they were young. Approximately, $76 \%$ of them did not attend any special classes but it is assumed that all of them attended at least 2 years of kindergarten where reading would have been taught. Chinese students in Malaysia are encouraged to begin reading young.

Even at kindergarten level, children are taught that reading is important yet most students are not motivated to read for leisure. This may be because a child at such a tender age has to learn to read in three languages. Students are tested on their reading skills and they are encouraged to do well in all three languages which sometimes put off reading for pleasure in the language of choice. Literature is also part of the exams in school which rather discourages reading for pleasure. Students have been encouraged to regard reading as school work from the start.

\section{Conclusion}

The answer to question, "What do Chinese students read for leisure?" is text books and materials such as journals and articles that help them do their assignments. During spare time, 
they read blogs and messages or chats when they log on to the net. Some also surf the net such as on YouTube for entertainment, but it usually involves little reading. Some respondents said that they sometimes read newspapers, magazines and comics on hardcopies but very few read story books or novels for leisure. They also do incidental reading such as reading subtitles when watching TV.

The answer to "What media, digital or print, do Chinese students prefer when they read for leisure?" is that they seem to have quite clear preference. When they are reading for exams, they read prints but many prefer reading from the digital media when they read for leisure. Many Chinese students own personal computers and smart phones. When in the past, people sat staring into space while at the bus-stop or waiting at government offices, nowadays, almost everyone is attached to a phone and is busily reading or sending text messages. If reading and writing text and blogs can be considered reading for leisure, then Chinese students are doing a lot of it.

The answer to "What language do Chinese students prefer when reading for pleasure?" is definitely their mother tongue, Chinese. Most Chinese students went through the Chinese education system and many Chinese are also very protective of their culture and language. Consequently, many Chinese choose to read Chinese newspapers and magazines. They also visit Chinese websites when they do light reading or when they are communicating with their Chinese friends but when they have to read for assignments, they will look for English websites.

As for the question, "Is there any relationship between early reading experiences and students' current reading habits?" more studies needed to be done on that topic. From this short survey, the result is not conclusive. Chinese students who mostly start reading quite early do not seem to have a healthy reading habit. They are reading because they have to and not because reading is a good way to pass time. They usually go for reading classes or to school to learn to read. The stress of going through reading classes and exams in more than one language could have affected Chinese students' reading habits for the worse.

Overall, Chinese students who are mostly bilingual in Chinese and English are lucky as they have so much reading materials they could choose from, yet many do not choose to read. People still need to learn how to read but there is now no need to 'read' if people choose not to after formal education where they have to. With advancement in the electronic media, reading books as a hobby might soon go the way of stamp collecting as a hobby and only done by a small group of old-fashioned people.

\section{References}

Berk, L. E. (2009). Child development ( $8^{\text {th }}$ Ed.). Pearson International Edition.

Kaur, S. \& Thivagarajah, R. (1999). The Reading Habits of ELLS Students in University Science Malaysia. Universiti Sains Malaysia. [Online] Available: http://www.ultibase.rmit.edu.au/Articles/Aug01/kaur.htm (Sep. 25, 2011) 
Kim, J. Y., \& Anderson, T. (2011). Reading across the curriculum: A framework for improving the reading abilities and habits of college students. Journal of College Literacy \& Learning, 37, 29-40.

Liu, Z. (2005). Reading behaviour in the digital environment: Changes in reading behaviour over the past ten year, Journal of Documentation. 61(6), 700-712. http://dx.doi.org/10.1108/00220410510632040

Nor Shahriza A. K. \& Amelia, H. (2007). Reading habits and attitude in the digital age: Analysis of gender and academic program differences in Malaysia. The Electronic Library, 25(3), 285-298. http://dx.doi.org/10.1108/02640470710754805

Ormrod, J. E. (2006). Educational psychology: Developing learners (5th Ed.). Pearson Merrill Prentice Hall.

Pandian, A. (2000). A study on readership behaviour among multi-ethnic, multi-lingual Malaysian students. Paper presented at the $8^{\text {th }}$ International Literacy and Educational Research Network (LERN) Conference on Learning, RMIT University, Melbourne, July 5-9.

Shen, L. (2006). Computer technology and college students' reading habits. Chia-Nan Annual Bulletin, 32,559-572.

Yang, A. (2007). Cultivating a reading habit: Silent reading at school. Asian EFL Journal, $9(2), 115-129$.

\section{Appendix}

Questionnaire:

\section{Please choose the option in each question that you feel is right for you.}

1. I am male

female

2. I went to Chinese Primary School. Sekolah Rendah Kebangsaan.

3. I go to Chinese Secondary School.

Sekolah Menengah Kebangsaan.

4. I learnt Chinese in school. I never learnt Chinese.

5. I can read Bahasa Malaysia.

Chinese. English. 
6. I can write Bahasa Malaysia.

_ Chinese. English.

7. I speak dialect at home with my family members.

En English

__ Mandarin

___ Bahasa Malaysia

8. I speak dialect with my Chinese friends.

English
Mandarin
Bahasa Malaysia

9. In my spare time, I usually play computer games. surf the net. watch TV. play sports. read. others (Please specify)

10. I usually read because I think I should.

__ I need to pass exams.

I I am interested in the topic or subject.

__ I need to while away some time.

I I think reading is fun.

11. I spend less than 1 hour reading every day.

1 to 2 hours.

2 to 3 hours.

3 to 4 hours.

more than 4 hours.

12. I usually read newspapers.

magazines. 
comics.

school text books.

on line (e-books, journals etc.).

13. I prefer reading soft copies such as on-line materials.

hardcopies such as books and magazines.

14. I prefer to read materials/books in Bahasa Malaysia.

Chinese.

English.

15. I prefer to use Bahasa Malaysia search engines.

Chinese.

English.

16. I prefer to use Bahasa Malaysia website.

Chinese

__ English

17. I prefer to use Bahasa Malaysia when I communicate with my friends on-line.

\section{Chinese}

English

18. I am on Facebook.

MSN.

twitter.

ICQ.

IRC. others (Please specify)

19. I usually read on-line articles and journals when I am on the computer. on-line news wikipedia manga/comics gaming and other information others (Please specify) 
20 When reading on-line, I prefer to read directly from the moniter screen.

print a hardcopy to read at leisure.

21. I spend less than 1 hour surfing the internet every day.
1 to 2 hours
2 to 3 hours
3 to 4 hours
__ more than 4 hours

22. I spend less than 1 hour playing on-line games every day.

$$
\begin{aligned}
& 1 \text { to } 2 \text { hours } \\
& 2 \text { to } 3 \text { hours } \\
& 3 \text { to } 4 \text { hours } \\
& \text { more than } 4 \text { hours }
\end{aligned}
$$

23. I learned to read in primary school. before primary school.

24. I attended special reading classes when I was young. did not attend any special reading classes when I was young. 